INSURANCE PRACTICE AND POLICY

\author{
CHRISTOPHER J. ROBINETTE, DANI WACHTEL \\ https://doi.org/10.33995/wu2019.4.5
}

\title{
Raising compulsory automobile insurance minimum amounts: a case study from the United States
}

This article discusses a decision both European Union Member States and states in the United States must make: whether to raise their compulsory automobile insurance minimum amounts. The authors review a case study from the United States, the Commonwealth of Pennsylvania, and conclude a proposed increase in the compulsory minimum amounts should pass the legislator. The purpose of compulsory automobile insurance is to compensate victims of automobile accidents. Due to inflation, the minimum amounts in Pennsylvania no longer compensate adequately. Moreover, the data do not support the contention that an increase in the minimum amounts will cause large increases in premiums and uninsured rates. The authors conclude that compulsory minimum amounts should be periodically reviewed, as they are in the European Union, and that arguments about large increases in premiums and uninsured rates should be subjected to a careful review based on data.

Key words: compulsory automobile insurance, compulsory third-party liability motor insurance, minimum amounts of coverage

\section{Introduction to compulsory automobile insurance amounts}

European Union Member States and states in the United States have compulsory automobile insurance laws, meaning motorists are required to purchase automobile insurance in order to drive legally. ${ }^{1}$ The laws specify certain minimum amounts of insurance coverage motorists must obtain.

1. An exception in the United States is the state of New Hampshire, which has a financial responsibility law. New Appleman on Insurance Law §61.02 [1], eds. J.E. Thomas and C.J. Robinette [LexisNexis 2011]. In New Hampshire, a motorist is not necessarily required to purchase automobile insurance. If, however, the motorist is convicted of certain motor vehicle violations or is involved in an accident in which someone is injured, killed 
Generally, motorists must purchase a minimum amount of liability coverage for bodily injury per person, a minimum amount of coverage for bodily injury per accident, and a minimum amount of property damage coverage per accident. ${ }^{2}$ In the United States, these limits are often expressed as a series of three numbers. For example, $25 / 50 / 10$ means there is $\$ 50,000$ available to cover all personal injuries in an accident, subject to a $\$ 25,000$ limit for any one person, and there is $\$ 10,000$ available for coverage of property damage from the accident. ${ }^{3}$

The compulsory minimum amounts set by the European Union and those set in the United States differ radically. The European Union requires motorists to obtain coverage of $€ 1,050,000$ per victim, $€ 5,210,000$ per claim, and $€ 1,050,000$ for property damage. ${ }^{4}$ The goal is that the "minimum amount of cover for personal injury should be calculated so as to compensate fully and fairly all victims who have suffered very serious injuries." ${ }^{5}$ Compulsory minimum amounts in the United States are much smaller. The United States has a federal structure in which the national and state governments have different, though often overlapping, responsibilities. Insurance law is primarily, but not exclusively, a state law issue; thus, the states set the minimum amounts required for automobile insurance. Those minimum amounts range from a low of $\$ 10,000 / \$ 20,000 / \$ 10,000$ in Florida to a high of $\$ 50,000 / \$ 100,000 / \$ 25,000$ in Maine and Alaska. ${ }^{6}$

Despite the range of minimums in the United States, even the highest minimum amounts are a small fraction of those required by the EU Directive. The reasons for that gap, and the ideal amount to set as a compulsory minimum, are beyond the scope of this essay. Instead, we explore a decision common to European Union states and states in the United States: should the compulsory minimum amounts, wherever they are set, be raised? For Member States of the European Union, the Motor Insurance Directive sets a floor each Member State must adopt to comply with European Union law. Member States are free to set higher minimums. States in the United States are also free to raise their minimum required amounts. In both cases, the issue is whether it makes sense as a matter of policy.

To examine the issue, we focus on a current attempt to raise the minimum required amounts in our state, Pennsylvania. The limits in Pennsylvania, $\$ 15,000 / \$ 30,000 / \$ 5,000$, ' were set in 1974 , nearly fifty years ago. Representative Aaron Kaufer has sponsored a bill to raise the minimum amounts to $\$ 30,000 / \$ 60,000 / \$ 15,000 .{ }^{8}$ In this case, we conclude the bill should pass. The purpose of compulsory automobile insurance is to compensate victims, and Pennsylvania's required

or there is property damage in excess of $\$ 1,000$, the motorist must furnish and maintain proof of financial responsibility to cover the damages caused and future damages. N.H. Rev. Stat. Ann. $§ \S 264: 2,264: 3$, 264:25. In addition, Virginia recently revised its statutes to allow motorists to pay an uninsured motorist fee as an alternative to compulsory insurance. Va. Code $\$ 46.2-706$.

2. J.E. Thomas and C.J. Robinette, “New Appleman ...", §61.02[3][b].

3. J.E. Thomas and C.J. Robinette, "New Appleman ...", §61.02 [3] [b]. Based on exchange rates in late January 2020, the equivalent in Euros is approximately €22,535/€45,070/€9,014.

4. Motor Insurance Directive 2009/103/EC, art. 9. Based on exchange rates in late January 2020, the equivalent in United States dollars is approximately $\$ 1,164,660 / \$ 5,778,932 / \$ 1,164,660$.

5. Motor Insurance Directive 2009/103/EC, recital 12.

6. Insurance Information Institute, Automobile Financial Responsibility Laws by State, https://www.iii.org/article/ background-on-compulsory-auto-uninsured-motorists (last visited Jan. 23, 2020).

7. 75 Pa.C.S.A. §1702.

8. 2019 PA H.B. 1625. 
amounts no longer do so adequately. Based on the rate of inflation since 1974, especially for medical services, an increase is necessary. Moreover, two of the objections often voiced to raising the minimum compulsory amounts, both in the United States and Europe, that premiums and uninsured rates will dramatically increase, are likely exaggerated.

\section{The need for reform in Pennsylvania}

\subsection{The purpose of compulsory automobile insurance is to compensate victims}

In general, liability insurance protects the insured from liability to those injured by the insured's unintentional tortious conduct. Compulsory automobile insurance, however, plays a different role: it was a legislative attempt to further the compensation of automobile accident victims. ${ }^{9}$ The statistical chasm between the percentage of victims compensated by insured drivers and those compensated by uninsured drivers led to pressure to mandate automobile insurance. ${ }^{10}$ Thus, as stated by the Supreme Judicial Court of Massachusetts: "The purpose of the compulsory motor vehicle insurance law is not, like ordinary insurance, to protect the owner or operator alone from loss, but rather is to provide compensation to persons injured through the operation of the automobile insured by the owner." ${ }^{11}$

\subsection{Pennsylvania's compulsory automobile insurance minimum amounts, established in 1974, are no longer adequate to compensate victims.}

Succinctly put, due to inflation, limits deemed adequate to compensate automobile accident victims in 1974 no longer are. Although the minimum amount of required automobile liability coverage has remained static over the years, the general cost of living in Pennsylvania is $388.71 \%$ higher than in 1974 when the rates were set. ${ }^{12}$ The value of $\$ 100$ in 1974 is equivalent to $\$ 488.71$ today. ${ }^{13}$ To make the point concrete, one commentator stated, "In 1974, the price of Kellogg's Corn Flakes was 43 cents, Pepsi Cola was 88 cents for a six-pack, and a Hershey bar was 15 cents." ${ }^{14}$ If the compulsory minimum amounts were updated for inflation, the $\$ 15,000$ requirement per person would

9. R.E. Keeton and J. O'Connell, Basic Protection for the Traffic Victim: A Blueprint for Reforming Automobile Insurance [Boston: Little, Brown 1965], 251.

10. C.J. Robinette, Why Civil Recourse Theory Is Incomplete, "Tennessee Law Review", 78[2] 2011, p. 468 n.326, citing P.J. Barringer et al., Administrative Compensation of Medical Injuries: A Hardy Perennial Blooms Again, "Journal of Health Politics, Policy and Law", 33 (4) 2008, p.732; G.T. Schwartz, Auto No-Fault and First-Party Insurance: Advantages and Problems, "Southern California Law Review", 73[3] 2000, p. 623.

11. Wheeler v. O'Connell, 9 N.E.2d 544, 546 (Mass. 1937).

12. CPI Inflation Calculator, https://www.in2013dollars.com/Philadelphia-Pennsylvania/price-inflation/1974-to2019? amount=100 (last visited Jan. 23, 2020). This inflation calculator uses data from the United States Bureau of Labor Statistics specific to certain cities. Philadelphia, Pennsylvania is one of the options. Thus, this inflation calculator allows us to be more accurate as to the rate of inflation in Pennsylvania, as opposed to a national rate of inflation.

13. CPI Inflation Calculator, https://www.in2013dollars.com/Philadelphia-Pennsylvania/price-inflation/1974-to2019? amount=100 (last visited Jan. 23, 2020).

14. Scott B. Cooper, Pa. minimum driving insurance coverage is dangerously low, The Patriot News, Dec. 10, 2010, https://www.pennlive.com/editorials/2010/12/pa_minimum_driving insurnace_c.html (last visited Jan. 23, 2020). 
become $\$ 73,306.97 ; ;^{15}$ the $\$ 30,000$ requirement per accident would become $\$ 146,613.95 ;{ }^{16}$ and the $\$ 5,000$ requirement for property damage would become $\$ 24,435.66$. $^{1 ?}$

As high as those increases seem, the personal injury coverage increases are almost certainly too low to reflect the specific increase in inflation. A significant portion of the damages covered by personal injury coverage is for medical care, and the rate of inflation for medical care has substantially outpaced the general rate of inflation. The inflation calculator selected allows users to focus on a particular sector of the economy, such as medical care. According to the U.S. Bureau of Labor Statistics, "prices for medical care were 1,076.47\% higher in 2019 [than they were in] 1974." 18 Medical care that cost $\$ 15,000$ in 1974 would cost $\$ 176,471.16$ today, representing a $\$ 161,471.16$ difference in value. ${ }^{19}$ Medical care that cost $\$ 30,000$ in 1974 would cost $\$ 352,942.33$ in 2019, a $\$ 322,942.33$ difference in value. ${ }^{20}$ The $\$ 15,000$ minimum for a single person is so low that anyone injured seriously enough to need a medical airlift will have exhausted the coverage just to pay to get the helicopter out of the hangar. The cost of a single emergency airlift on the Life Lion Critical Care Transport unit at Penn State Hershey Medical Center in Hershey, Pennsylvania costs a flat fee of $\$ 24,205$, with an additional rate of $\$ 301$ per mile traveled. ${ }^{21}$

Additionally, for purposes of property damage coverage, the cost of vehicles has also increased dramatically since the mid-1970s when the compulsory rates were set. The average cost of a car in 1974 was $\$ 4,441,{ }^{22}$ with many cars priced between $\$ 2,000$ and $\$ 5,000 .{ }^{23}$ In 2019 , the average transaction price for the auto industry as a whole was $\$ 37,149 .{ }^{24}$ Broken down by segment, the average transaction price for a full-size car was $\$ 35,327$, a mid-sized car $\$ 25,951$, and a compact car $\$ 20,504 .^{25}$

15. CPI Inflation Calculator, https://www.in2013dollars.com/Philadelphia-Pennsylvania/price-inflation/1974-to2019? amount=15000 (last visited Jan. 23, 2020).

16. CPI Inflation Calculator, https://www.in2013dollars.com/Philadelphia-Pennsylvania/price-inflation/1974-to2019 ?amount=30000 (last visited Jan. 23, 2020).

17. CPI Inflation Calculator, https://www.in2013dollars.com/Philadelphia-Pennsylvania/price-inflation/1974-to2019? amount $=5000$ (last visited Jan. 23, 2020).

18. CPI Inflation Calculator, https://www.in2013dollars.com/Medical-care/price-inflation/1974-to2019? amount=15000 (last visited Jan. 23, 2020).

19. CPI Inflation Calculator, https://www.in2013dollars.com/Medical-care/price-inflation/1974-to2019? amount=15000 (last visited Jan. 23, 2020).

20. CPI Inflation Calculator, https://www.in2013dollars.com/Medical-care/price-inflation/1974-to2019? amount $=30000$ (last visited Jan. 23, 2020).

21. Interview by Dani Wachtel with Melissa Singh, Financial Navigator, Penn State Health Milton S. Hershey Medical Center in Hershey, Pa. (December 17, 2019). This cost is not unusual; air ambulance rates increased about 60\% from 2012 until 2016, to a median of $\$ 39,000$. Christopher Rowland, Why the flight to the hospital is more costly than ever, Wash. Post, July 1, 2019, https://www.washingtonpost.com/business/economy/why-the-flight-to-the-hospital-is-morecostly-than-ever/2019/07/01/9dd66736-99dc-11e9-916d-9c61607d8190_story.html (last visited Jan. 29, 2020).

22. WGNTV, https://wgntv.com/2016/04/25/the-average-car-now-costs-25449-how-much-was-a-car-the-year-youwere-born/ (last visited Jan 23, 2020). The analysis was based on data from the U.S. Bureau of Economic Analysis.

23. The Consumer Guide, https://blog.consumerguide.com/the-10-best-cars-of-1974/ (last visited Jan. 23, 2020).

24. Kelley Blue Book, https://mediaroom.kbb.com/2019-02-01-Average-New-Car-Prices-Up-More-Than-4-Percent-YearOver-Year-for-January-2019-on-Tesla-Full-Size-Trucks-According-to-Kelley-Blue-Book (last visited Jan. 23, 2020).

25. Kelley Blue Book, https://mediaroom.kbb.com/2019-02-01-Average-New-Car-Prices-Up-More-Than-4-Percent-YearOver-Year-for-January-2019-on-Tesla-Full-Size-Trucks-According-to-Kelley-Blue-Book (last visited Jan. 23, 2020). 


\subsection{Pennsylvania's compulsory automobile insurance minimum amounts are lower than the minimum amounts in almost every other state.}

Pennsylvania has become an outlier; its compulsory automobile insurance requirements are among the lowest in the nation. Of all the jurisdictions, only Florida requires less coverage: $\$ 10,000$ in personal injury protection, $\$ 20,000$ per accident, and $\$ 10,000$ property damage liability. ${ }^{26}$ California and New Jersey require the same amount of coverage as Pennsylvania. ${ }^{27}$ All of the remaining jurisdictions require more coverage than Pennsylvania. ${ }^{28}$

\section{Concerns about large increases in premiums and uninsured rates are likely exaggerated.}

\subsection{Two common objections to raising compulsory automobile insurance minimum amounts are large increases in premiums and uninsured rates.}

Opponents of increasing compulsory automobile insurance amounts frequently raise two objections. First, an increase in compulsory minimum amounts will lead to a large increase in premiums. Second, such a large increase in premiums will lead to motorists opting out of coverage entirely and going uninsured. We acknowledge that an increase in compulsory minimum amounts will lead to increases in premiums for motorists who are insured at or just above the current minimum amounts. A motorist should and will pay more when she is receiving more protection through insurance coverage. We further acknowledge that we cannot predict with any certainty the precise amount of the likely increase. The data suggest, however, that the increases are unlikely to be large. The data further show there is no necessary connection between higher compulsory minimum amounts and higher uninsured rates, and that increases in those minimum amounts are unlikely to have a large impact on the uninsured rate.

\subsection{An increase in Pennsylvania's compulsory automobile insurance amounts will likely lead to a modest increase in premiums for those motorists covered at or just above the current minimum amounts.}

Not all motorists would be directly affected by an increase in the compulsory minimum amounts. The direct effect of an increase in compulsory minimum insurance amounts will only impact those motorists who are covered at or just above the current minimum amounts. Unfortunately, we are

26. Insurance Information Institute, Automobile Financial Responsibility Laws by State, https://www.iii.org/article/ background-on-compulsory-auto-uninsured-motorists (last visited Jan. 23, 2020). Personal Injury Protection is no-fault coverage, covering the driver regardless if she is at fault in causing an accident.

27. Insurance Information Institute, Automobile Financial Responsibility Laws by State, https://www.iii.org/article/ background-on-compulsory-auto-uninsured-motorists (last visited Jan. 23, 2020).

28. Insurance Information Institute, Automobile Financial Responsibility Laws by State, https://www.iii.org/article/ background-on-compulsory-auto-uninsured-motorists (last visited Jan. 23, 2020). Arizona and Louisiana only require more property damage coverage than Pennsylvania. Arizona requires 15/30/10 and Louisiana requires 15/30/25. 
aware of no definitive data regarding the number of motorists who would be affected by an increase in the compulsory minimum amounts. When recently asked how many motorists are purchasing minimum coverage, an insurance sales representative responded, "not that many." 29 Nearly a decade ago, a commentator estimated the number of motorists purchasing minimum coverage at about twelve percent. ${ }^{30}$ In addition to motorists covered at the minimum amounts, an increase to $30 / 60 / 15$ would also affect the personal injury coverage of motorists insured at 25/50/25, a coverage amount commonly offered by insurers in Pennsylvania.

The data show that recent increases in the compulsory minimum amounts in other jurisdictions have a minimal effect on the average cost of automobile insurance. Table 1 includes the last five jurisdictions to increase the compulsory minimum amounts for which data on average automobile insurance premiums are available. The average annual premium price is included for the year before the change, year the change was implemented, and the year after the change.

Table 1. Average Annual Cost of Insurance Before and After State Minimums Increased ${ }^{31}$

\begin{tabular}{|c|c|c|c|c|}
\hline State & Year of Increase & $\begin{array}{l}\text { Average Cost of Ins. } \\
\text { Year Prior to Change }\end{array}$ & $\begin{array}{c}\text { Average Cost of Ins. } \\
\text { Year of Change }\end{array}$ & $\begin{array}{l}\text { Average Cost of Ins. } \\
\text { Year After Change }\end{array}$ \\
\hline Illinois & 2015 & 775.24 & 803.64 & 836.67 \\
\hline Ohio & 2013 & 634.91 & 659.37 & 682.71 \\
\hline Maryland & 2011 & 947.74 & 956.17 & 966.29 \\
\hline Texas & 2011 & 848.11 & 842.58 & 823.80 \\
\hline Louisiana & 2010 & $1,121.44$ & $1,110.68$ & $1,112.53$ \\
\hline
\end{tabular}

In 2015, Illinois increased its compulsory minimum amounts. ${ }^{32}$ The following year, the average cost of automobile insurance in Illinois increased $\$ 33.03$ per year ( $\$ 2.75$ per month), an increase of $4.1 \%$. In 2013, Ohio increased its compulsory minimum amounts. ${ }^{33}$ The following year, the average cost of automobile insurance in Ohio increased $\$ 23.34$ per year ( $\$ 1.95$ per month), an increase of 3.5\%. In 2011, Maryland increased its compulsory minimum amounts. ${ }^{34}$ The following year, the average cost of automobile insurance in Maryland increased $\$ 10.12$ per year $(\$ .84$ per month), an increase of $1.1 \%$. Also in 2011 , Texas increased its compulsory minimum amounts. ${ }^{35}$ The following year, the average cost of automobile insurance in Texas decreased by $\$ 18.78$ per year ( $\$ 1.57$ per month), a decrease of 2.2\%. Finally, in 2010, Louisiana increased its compulsory

29. Interview by Dani Wachtel with Tawana Williams, Licensed Sales Representative, MetLife, (New York) (Jan. 22, 2020).

30. Scott B. Cooper, Pa. minimum driving insurance coverage is dangerously low, THE PATRIOT NEWS, Dec. 10, 2010, https://www.pennlive.com/editorials/2010/12/pa_minimum_driving insurnace_c.html (last visited Jan. 23, 2020).

31. Insurance Information Institute, "Archived Tables," https://www.iii.org/table-archive/21247 (last visited Jan. 26, 2020).

32. 625 III. Comp. Stat. Ann. 5/7-317. The amounts increased from 20/40/15 to 25/50/20. 2013 III. Legis. Serv. P.A. 98-519 (S.B. 1898).

33. Ohio Rev. Code Ann. § 4509.01. The amounts increased from 12/25/7 to 25/50/25. 2012 Ohio Laws File 181 (Am. Sub. H.B. 278).

34. MD TRANS § 17-103. The amounts increased from 20/40/15 to 30/60/15. 2010 Maryland Laws Ch. 441 (H.B. 825).

35. Tex. Transp. Code Ann. $§ 601.072$. The amounts increased from 25/50/25 to 30/60/25. 2007 Tex. Sess. Law Serv. Ch. 1298 [S.B. 502]. 
minimum amounts. ${ }^{36}$ The following year, the average cost of automobile insurance in Louisiana increased $\$ 1.85$ per year ( $\$ .15$ per month), an increase of . $2 \%$.

Table 2. National Average Annual Cost of Automobile Insurance. ${ }^{37}$

\begin{tabular}{|l|c|c|}
\hline \multicolumn{1}{|c|}{ Year } & $\begin{array}{c}\text { Average Cost } \\
\text { of Insurance }\end{array}$ & Percent Change \\
\hline 2010 & 789.29 & 0.3 \\
\hline 2011 & 795.00 & 0.7 \\
\hline 2012 & 812.19 & 2.2 \\
\hline 2013 & 838.49 & 3.2 \\
\hline 2014 & 866.31 & 3.2 \\
\hline 2015 & 889.01 & 2.7 \\
\hline 2016 & 935.80 & 5.3 \\
\hline
\end{tabular}

Even the largest of the increases is not dramatic, and the increases seem even less significant when viewed in context. It is not clear what portion, if any, of the increases are caused by raising the compulsory minimum amounts. For example, the largest annual increase, in Illinois, was $\$ 33.03$ after raising the minimum amounts, a $4.1 \%$ increase. The same year, however, the national percentage increase in annual insurance costs was 5.3\%, over one percent higher than Illinois' increase. Ohio is a similar case; the year after the compulsory minimum amounts were raised, automobile insurance premiums increased $\$ 23.34$, a 3.5\% increase. The same year, the national percentage increase in annual insurance costs was 3.2\%, just a little below Ohio's percentage increase. Maryland (1.1\%; national average $2.2 \%$ ), Texas (decrease of $2.2 \%$; national average increase of $2.2 \%$ ), and Louisiana (.1\%; national average .7\%) all experienced a smaller percentage increase in cost than the national average the year after compulsory minimum amounts were increased.

Thus, the average price for automobile insurance in Pennsylvania is unlikely to increase significantly due to an increase in compulsory minimum amounts. Moreover, the premiums for those directly affected by the increase in compulsory minimum amounts is likely to be modest. The reason is that the most expensive insurance coverage is always the lower amounts, those most likely to be needed. As the coverage amounts increase, the additional coverage becomes increasingly cheaper.

As an example, during the time we were writing this paper, one of us (Wachtel) was also searching for automobile insurance coverage. She kept a record of her search, and the results are illustrative. We recognize that the cost of automobile insurance depends on many factors and that a sample size of one is insignificant. We do not claim the data can be used to suggest an average cost for automobile insurance, or even that we could derive an average amount of the likely increase. We do believe, however, that the relatively small amounts charged as the coverage increases from one level to another suggest that price increases for the additional amounts of coverage will be modest.

36. La. Stat. Ann. § 32:900. The amounts increased from 10/20/10 to 15/30/25. 2008 La. Sess. Law Serv. Act 921 (H.B. 1312).

37. Insurance Information Institute, "Facts + Statistics: Auto Insurance," https://www.iii.org/fact-statistic/factsstatistics-auto-insurance (last visited Jan. 26, 2020). 
Wachtel contacted all of the insurers presented in the table by visiting the insurer's website and/or calling and speaking with a Licensed Sales Agent. ${ }^{38}$ She requested monthly full-tort estimates at the current minimum level, 15/30/5, as well as 25/50/25, and 100/300/100. She was unable to obtain estimates for the proposed minimum amounts of $30 / 60 / 15$. The most analogous amounts, $25 / 50 / 25$, has less personal injury coverage and more property damage coverage than the proposed minimum amounts. The potential insured is a 33-year-old single female with a bachelor's degree, working and driving in the Harrisburg, Pennsylvania area. She rents an apartment in the 17109 zip code. Wachtel was licensed to drive at the age of 16 and she currently drives a 2017 Volkswagen Jetta, 1.4 S Sedan 4D, which was new at the time she obtained the vehicle. The vehicle is leased, and the driver has a "good" credit rating according to her 2019 FICO credit score report. Wachtel has had one accident in the past five years. She uses her car for work and pleasure and drives about 12,000 miles per year. Wachtel has not participated in any safe or defensive driving courses, but would be open to other discounts such as automatic bill pay, if offered. She also does not participate in any bundling of other insurance policies with any of the insurers interviewed.

Table 3. Monthly Premium Estimates

\begin{tabular}{|l|c|c|c|c|c|c|c|} 
& Allstate & Erie & Geico & MetLife & $\begin{array}{c}\text { National } \\
\text { General }\end{array}$ & Progressive & State Farm \\
\hline $15 / 30 / 5$ & 136 & & 122 & 182 & 196 & 55 & 193 \\
\hline $25 / 50 / 25$ & $141^{39}$ & 102 & 127 & 191 & $203^{40}$ & 65 & 204 \\
\hline $100 / 300 / 100$ & & 109 & 130 & 204 & 209 & 76 & 231 \\
\hline
\end{tabular}

Several things are striking to us about the data. First, the amount of the increase from the minimum to the next level ranges from $\$ 5$ to $\$ 11$ per month. Thus, for example, at Geico, one can purchase the first $15 / 30 / 5$ for $\$ 122$ a month; an additional $10 / 20 / 20$, however, only costs $\$ 5$. Second, in some cases the cost to transition from a small amount of insurance to a much larger amount is negligible. For example, at Geico $\$ 8$ a month is the difference between 15/30/5 and 100/300/100. Erie does not sell the minimum coverage, which is interesting in itself, but $\$ 7$ a month is the difference between $25 / 50 / 25$ and $100 / 300 / 100$. Third, the amount of price fluctuation is surprising. The difference between the minimum coverage and 100/300/100 at Progressive is \$21, which

38. Dani Wachtel contacted the following insurers: Allstate, Erie, Geico, MetLife, National General Insurance, Progressive, and State Farm. The Allstate quote was offered on January 19, 2020 by Allstate, 3876 Union Deposit Road, Harrisburg, PA 17109, by visiting their website at https://www.allstate.com/. The Erie quote was offered on January 19, 2020 by Erie Insurance, 75 Houcks Road, Suite 301, Harrisburg, PA 17109, by visiting their website at https://www.erieinsurance.com/. The Geico quote was offered on January 23, 2020 by Geico, One Geico Plaza, Washington, D.C. 20076, by calling a Licensed Agent at 800-841-2964. The MetLife quote was offered on January 22, 2020 by MetLife, 200 Park Avenue, New York, NY 10166, by calling a Licensed Agent at 888-995-7606. The National General Insurance quote was offered on January 19, 2020 by National General Insurance, 5630 University Parkway, Winston-Salem, NC 27105, by visiting their website at http:// www.nationalgeneral.com/. The Progressive quote was offered on January 19, 2020 by Progressive Advanced Insurance Co., 6300 Wilson Mills Road, Mayfield Village, $\mathrm{OH} 44143$, by visiting their website at https://www. progressive.com/. The State Farm quote was offered on January 19, 2020 by State Farm, 1300 N. Mountain Road, Linglestown, PA 17112, by visiting their website at https://www.statefarm.com/.

39. Quote based on 30/85/25. Wachtel received contradictory information about Allstate's quote for 100/300/100; we do not include information for that category.

40. Quote based on $25 / 50 / 15$. 
is higher than the examples we just listed, but the total amount per month is $\$ 76$, which is small compared to the other estimates.

We believe concerns about a large increase in premiums, even for those directly affected by raising the compulsory minimum amounts, are exaggerated. On the low end, ${ }^{41}$ someone with Wachtel's statistics could move from the current minimum to 30/85/25, above the proposed minimum amounts, for $\$ 5$ a month. We understand that $\$ 5$ a month can be an onerous expense for those struggling to make ends meet. One in an accident, however, is as likely to be the injured as to be the injurer, as likely to need compensation as to need the protection of liability insurance. The increase in compulsory minimum amounts is actually more useful to those struggling to make ends meet. If they are injured in an automobile accident, they are the ones who will most need the compensation mandated by statute, because they are the least likely to have other means to pay for any resulting medical bills and lost wages.

\subsection{Raising Pennsylvania's compulsory automobile insurance minimum amounts is likely to have a negligible impact on Pennsylvania's uninsured rate.}

The percentage of motorists driving without insurance is not necessarily related to the compulsory minimum amounts imposed by a jurisdiction. In 2015, the latest year for which data are available, the jurisdiction with the highest uninsured motorist rate imposed the smallest required amounts of insurance and the jurisdiction with the lowest uninsured motorist rate imposed the highest required amounts of insurance. ${ }^{42}$ Florida imposes the least stringent limits among all of jurisdictions, 10/20/10, and yet in 2015 had the highest percentage of uninsured drivers, a staggering 26.7 percent. ${ }^{43}$ On the other hand, Maine requires 50/100/25, and had the lowest rate of uninsured drivers at 4.5 percent. ${ }^{44}$ This same year nationwide, the percentage of motorists without automobile insurance was $13 .{ }^{45}$

The data show that recent increases in the compulsory minimum amounts in other jurisdictions have a minimal effect on the uninsured motorist rates. Table 4 includes the last seven jurisdictions to increase the compulsory minimum amounts for which data on uninsured rates are available.

41. The concept of "cherry-picking," or using the data most favorable to one's argument is not a large concern in this context. These are price quotations, and the consumer will actually select the insurance she wants. If cost is a major concern, she may select the least costly option.

42. Insurance Information Institute, "Facts + Statistics: Uninsured Motorists," https://www.iii.org/fact-statistic/ facts-statistics-uninsured-motorists (last visited Jan. 22, 2020).

43. Fla. Stat. Ann. § 324.021; Insurance Information Institute, "Facts + Statistics: Uninsured Motorists," https://www.iii.org/fact-statistic/facts-statistics-uninsured-motorists (last visited Jan. 22, 2020).

44. Me. Rev. Stat. tit. 29-A, § 1605; Insurance Information Institute, "Facts + Statistics: Uninsured Motorists," https://www.iii.org/fact-statistic/facts-statistics-uninsured-motorists (last visited Jan. 22, 2020). The other state requiring 50/100/25 had an uninsured rate of $15.4 \%$.

45. Insurance Information Institute, "Facts + Statistics: Uninsured Motorists," https://www.iii.org/fact-statistic/ facts-statistics-uninsured-motorists (last visited Jan. 22, 2020). 
Table 4. Percentage of Uninsured Motorists by State Before and After Increase. ${ }^{46}$

\begin{tabular}{|c|c|c|c|c|c|}
\hline State & Year of Increase & $\begin{array}{c}\text { Percentage } \\
\text { of Uninsured } \\
\text { Motorists in } 2007\end{array}$ & $\begin{array}{c}\text { Percentage } \\
\text { of Uninsured } \\
\text { Motorists in } 2009\end{array}$ & $\begin{array}{c}\text { Percentage } \\
\text { of Uninsured } \\
\text { Motorists in } 2012\end{array}$ & $\begin{array}{c}\text { Percentage } \\
\text { of Uninsured } \\
\text { Motorists in } 2015\end{array}$ \\
\hline Alabama & 2009 & 26 & 21.8 & 19.6 & 18.4 \\
\hline Oregon & 2009 & 11 & 10.4 & 9.0 & 12.7 \\
\hline Utah & 2009 & 8 & 8.2 & 5.8 & 8.2 \\
\hline Louisiana & 2010 & 12 & 12.9 & 13.9 & 13 \\
\hline Maryland & 2011 & 12 & 14.9 & 12.2 & 12.4 \\
\hline Texas & 2011 & 15 & 14.9 & 13.3 & 14.1 \\
\hline Ohio & 2013 & 16 & 15.7 & 13.5 & 12.4 \\
\hline
\end{tabular}

Of the last seven states to increase their compulsory minimum insurance amounts for which data are available, the uninsured rate actually decreased in six of them. In 2013, Ohio increased its compulsory minimum amounts, ${ }^{47}$ and the uninsured rate fell from $13.5 \%$ in 2012 to $12.4 \%$ in 2015. In 2011, Texas increased its compulsory minimum amounts, ${ }^{48}$ and the uninsured rate fell from $14.9 \%$ in 2009 to $13.3 \%$ in 2012. Also in 2011, Maryland increased its compulsory minimum amounts, ${ }^{49}$ and the uninsured rate fell from $14.9 \%$ in 2009 to $12.2 \%$ in 2012. In 2010, Louisiana increased its compulsory minimum amounts, ${ }^{50}$ and the uninsured rate rose from $12.9 \%$ in 2009 to $13.9 \%$ in 2012 . In 2009, Utah raised its compulsory minimum amounts, ${ }^{51}$ and the uninsured rate fell from $8.2 \%$ in 2009 to $5.8 \%$ in 2012. Also in 2009, Oregon increased its compulsory minimum amounts, ${ }^{52}$ and the uninsured rate fell from $10.4 \%$ in 2009 to $9.0 \%$ in 2012 . Finally, again in 2009 , Alabama increased its compulsory minimum amounts, ${ }^{53}$ and the uninsured rate fell from $21.8 \%$ in 2009 to $19.6 \%$ in 2012 .

46. Insurance Information Institute, "Archived Tables," https://www.iii.org/table-archive/20641 (last visited Jan. 26, 2020).

47. Ohio Rev. Code Ann. § 4509.01. The amounts increased from 12/25/7 to 25/50/25. 2012 Ohio Laws File 181 (Am. Sub. H.B. 278).

48. Tex. Transp. Code Ann. § 601.072. The amounts increased from 25/50/25 to 30/60/25. 2007 Tex. Sess. Law Serv. Ch. 1298 [S.B. 502].

49. MD TRANS § 17-103. The amounts increased from 20/40/15 to 30/60/15. 2010 Maryland Laws Ch. 441 (H.B. 825).

50. La. Stat. Ann. § 32:900. The amounts increased from 10/20/10 to 15/30/25. 2008 La. Sess. Law Serv. Act 921 (H.B. 1312).

51. Utah Code Ann. § 31A-22-304. The amounts increased from $25 / 50 / 15$ to $25 / 65 / 15$. 2008 Utah Laws Ch. 371 (S.B. 149).

52. Or. Rev. Stat. Ann. $§ 806.070$. The amounts increased from $15 / 50 / 10$ to $25 / 50 / 20.2009$ Oregon Laws Ch. 66 (H.B. 2326).

53. Ala. Code $\S 32-7-6$. The amounts increased from $20 / 40 / 10$ to $25 / 50 / 25$. 
Table 5. National Uninsured Motorist Rate ${ }^{54}$

\begin{tabular}{|l|c|}
\hline \multicolumn{1}{|c|}{ Year } & Percentage of Uninsured Motorists \\
\hline 2008 & 14.3 \\
\hline 2009 & 13.8 \\
\hline 2010 & 12.3 \\
\hline 2011 & 12.3 \\
\hline 2012 & 12.6 \\
\hline 2013 & 12.7 \\
\hline 2014 & 13.0 \\
\hline 2015 & 13.0 \\
\hline
\end{tabular}

The nationwide uninsured motorist rates provide context for the data. Ohio increased its compulsory minimum amounts in 2013 and the uninsured rate in Ohio fell $8.1 \%$ between 2012 and 2015 (from 13.5\% to 12.4\%). During the same period, the nationwide uninsured rate increased by $3.2 \%$ (from $12.6 \%$ to $13.0 \%$ ). Of the six states increasing their compulsory minimum amounts between 2009 and 2012, all but one experienced decreases in their uninsured rates that were better than the national average. On a national basis, the uninsured rate decreased $8.7 \%$ (from $13.8 \%$ to $12.6 \%$ ) from 2009 to 2012 . Texas at a decrease of $10.7 \%$ (from $14.9 \%$ to $13.3 \%$ ), Maryland at $18.1 \%$ (from $14.9 \%$ to $12.2 \%$ ), Utah at $29.3 \%$ (from $8.2 \%$ to $5.8 \%$ ), Oregon at $13.5 \%$ (from $10.4 \%$ to 9.0 ), and Alabama at $10.1 \%$ ( from $21.8 \%$ to $19.6 \%$ ) all outperformed the national average despite raising the compulsory minimum amounts. The only outlier is Louisiana, which had an increase of $7.8 \%$ ( from $12.9 \%$ to $13.9 \%$ ) when the national average was a decrease of $8.7 \%$. ${ }^{55}$ Thus, on the issue of changes in the uninsured rate, six of the seven states outperformed the national average, several by large margins. The data do not support the contention that increasing the compulsory

54. Insurance Information Institute, "Facts + Statistics: Uninsured Motorists," https://www.iii.org/fact-statistic/ facts-statistics-uninsured-motorists (last visited Jan. 28, 2020).

55. We have no explanation for what happened in Louisiana, but the size of the increase in Louisiana's compulsory minimum amounts does not seem to be the cause of the increase in the percentage of uninsured motorists. Louisiana increased its amounts from 10/20/10 to 15/30/25, an increase of 5/10/15. La. Stat. Ann. §32:900; 2008 La. Sess. Law. Serv. Act 921 (H.B. 1312). Louisiana's increase was similar to increases in other states, and smaller than increases in Ohio and, in two categories, Maryland, the states with the largest increases in the group. Ohio increased from 12/25/7 to 25/50/25, an increase of 13/25/18. Ohio Rev. Code Ann. § 4509.01; 2012 Ohio Laws File 181 (Am. Sub. H.B. 278). Ohio's uninsured rate fell $8.1 \%$ at the same time the nationwide uninsured rate increased by 3.2\%. Maryland increased its amounts from 20/40/15 to 30/60/15, an increase of 10/20/0. MD TRANS. § 17-103; 2010 Maryland Laws Ch. 441 (H.B. 825). Maryland's uninsured rate fell $18.1 \%$ at the same time the nationwide uninsured rate fell only $8.7 \%$.

Pennsylvania's increase in its compulsory minimum amounts, 15/30/10, would be at the high end of the increases discussed in this article. The most analogous increases are in Ohio and Maryland. Ohio's increase, 13/25/18, is very similar. Maryland, a neighboring state, had an increase of 10/20/0. Moreover, Maryland's new minimum amounts, 30/60/15, are the same as Pennsylvania's proposed amounts. As discussed, both Ohio and Maryland outperformed national changes in the uninsured rate despite increases in compulsory minimum amounts. Additionally, the year after increases in minimum compulsory amounts, Ohio's average annual automobile insurance premiums increased slightly more than the national average (3.5\% versus 3.2\%). The year after increases in minimum compulsory amounts, Maryland's average annual automobile insurance premiums increased less than the national average (1.1\% versus $2.2 \%$. The data do not support the conclusion that Pennsylvania's increase in compulsory minimum amounts would be too large. 
minimum amounts leads to an increase in the uninsured rate; indeed it is possible there is little or no relationship between those sets of data.

\section{Conclusions}

Both European Union Member States and states in the United States face the decision of whether to raise the compulsory automobile insurance minimum amounts. Reviewing the case of Pennsylvania is instructive for two reasons. First, it demonstrates the European Union legislator is wise to review and update the compulsory minimum amounts on a regular basis. The European Union legislator will not allow the minimum amounts to become so diminished by inflation as Pennsylvania, which has not increased its minimum amounts in nearly fifty years. Jurisdictions in the United States should review their compulsory minimum amounts at least once a decade. Second, arguments about large increases in premium costs and uninsured rates should be reviewed carefully. Although there is an intuitive appeal to the arguments, one must review the data. In the case of Pennsylvania, the surveyed data do not support fears of large increases in premiums and uninsured rates. The Pennsylvania General Assembly should pass Representative Kaufer's bill.

\section{Bibliography}

Barringer P.J. et al., Administrative Compensation of Medical Injuries: A Hardy Perennial Blooms Again, "Journal of Health Politics, Policy and Law", 33[4] 2008

Cooper S.B., Pa. minimum driving insurance coverage is dangerously low, THE PATRIOT NEWS, Dec. 10, 2010, https://www.pennlive.com/editorials/2010/12/pa minimum_driving insurnace_c.html Keeton R.E. and O'Connell J., Basic Protection for the Traffic Victim: A Blueprint for Reforming Automobile Insurance, Boston, Little, Brown 1965

Robinette C.J., Why Civil Recourse Theory Is Incomplete, "Tennessee Law Review", 78 (2) 2011 Rowland Ch., Why the flight to the hospital is more costly than ever, Wash. Post, July 1, 2019, https:// www.washingtonpost.com/business/economy/why-the-flight-to-the-hospital-is-more-costlythan-ever/2019/07/01/9dd66736-99dc-11e9-916d-9c61607 d8190_story.html

Schwartz G.T., Auto No-Fault and First-Party Insurance: Advantages and Problems, "Southern California Law Review", 73(3) 2000

Thomas J.E. and Robinette C.J., New Appleman on Insurance Law §61.02 [1], LexisNexis 2011

\section{Podniesienie minimalnej sumy gwarancyjnej w obowiązkowym ubezpieczeniu odpowiedzialności cywilnej posiadaczy pojazdów mechanicznych: studium przypadku ze Stanów Zjednoczonych}

W artykule omówiono kwestię podniesienia minimalnych sum gwarancyjny w obowiqzkowych ubezpieczeniach odpowiedzialności cywilnej posiadaczy pojazdów mechanicznych. Autorzy przedstawiaja studium przypadku ze Stanów Zjednoczonych - stanu Pensylwanii. Według autorów ustawodawca powinien podwyższyć minimalne sumy gwarancyjne, takjak ma to miejsce w Unii Europejskiej. 
Z uwagi na występujacq inflację, kwoty minimalnych sum gwarancyjnych w Pensylwanii sq niewystarczajace i nie zapewniaja przyznania odpowiedniego odszkodowania ofiarom. Przeprowadzone badana nie wskazuja, aby zwiększenie minimalnych kwot sum gwarancyjnych spowodowało znaczny wzrost składek ubezpieczeniowych oraz odsetek podmiotów nieubezpieczonych.

Słowa kluczowe: obowiązkowe ubezpieczenie odpowiedzialności cywilnej posiadaczy pojazdów mechanicznych, minimalne sumy gwarancyjne

CHRISTOPHER J. ROBINETTE - Professor of Law, Widener Commonwealth University Law School, member of the European Group on Tort Law.

e-mail: cjrobinette@widener.edu

DANI WACHTEL - Widener University Commonwealth Law School, Class of 2020.

e-mail: Wachtel.Dani@gmail.com 
